DEPARTAMENTO DE EPIDEMIOLOGLA I PROFLAXIA GERAIS E ESPECIAIS

(Diretor: Prot. F. Borges Vleira)

CADEIRA DE DIAGNOSTICO DAS DOENÇAS TRANSMISSIVEIS

(Prot. Dr. Joào Alves Meira)

DEPARTAMENTO DE PARASITOLOGIA

(Diretor: Prof. Dr. Paulo Cesar de Azevedo Antunes)

CONSIDERAÇÕES SOBRE A FASE LARVARIA DA INFECÇÃO ANCILOSTOMótICA. SÔBRE DOIS CASOS CLINICOS IE ANCILOSTOMIASE AGUDA *

\author{
JOAO ALVES MEIRA \\ e \\ A. L. AYROSA GALVAO
}

Segundo Ashford ${ }^{1}$, existem duas formas clínicas de ancilostomose. A forma aguda, relativamente rara, e a crônica, que pode ser leve, moderada ou grave, e ainda acompanhada de exacerbações agudas pelas reinfecções sucessivas nos indivíduos repetidamente expostos, periódica ou acidentalmente, às larvas infes. tantes dos parasitas. A ancilostomose aguda, única que nos interessa no presente trabalho, seria consequente à invasão maciça e abrupta das larvas filarióides, aparecendo os sintomas agudos correspondentes, usualmente, dois a três meses após a penetração larvária, exceção feita para as manifestações cutâneas (der. matite ancilostomótica, "ground itch"), que já se podem evidenciar dentro de poucas horas depois do contacto das partes do corpo com o solo poluido.

Fstas formas clínicas da ancilostomose foram estahelecidas em base de gran. de número de observaçōes realizadas em Porto Rico e publicadas no relatório da Commission for the Study and Treatment of Anemia ${ }^{2}$.

Conquanto esta subdivisão das formas clínicas da ancilostome tenha sido aceita por autoridades na matéria, como por exemplo Chandler ${ }^{6}$ e Faust ${ }^{10}$, além de outros, pouco tem sido publicado, entretanto, com referência à forma aguda da parasitose. Entre nós, Martinho da Rocha Jr. ${ }^{15}$ publicou em 1930 uma interessante observação que rotulou com o nome de "um caso curioso de ancylostomose". Em resumo, tratava-se de um robusto menino de 11 anos e 7 meses de idade, pertencente a família abonada e que depois de brincar durante $15 \mathrm{minu}$ tos, descalço, no barro que era amassado para fazer tijolos, numa fazenda de seu pai, começou logo a sentir prurido nos pés e pernas, onde apareceram "holinhas" nas partes da pele em contacto com o barro. Nos dias seguintes o menor apresentou tosse forte e bronquite. Em seguida êle tornou-se pálido. Foi feito um exame de fézes que resultou negativo. Dois meses mais tarde a palidez era mais pronunciada, sendo repetido o exame de fézes, com igual resultado. O estado do paciente então se agravou. Ele tornou-se extremamente anêmico, mostrando o exame de sangue um baixo teor hemoglobínico. $O$ paciente foi submetido a vários tratamentos sem nenhum proveito, e, por fim, foi-lhe aconselhado mudança de clina. O paciente foi então examinado pelo citado autor em Teresópolis, que verificou tratar-se de criança bem constituida, emagrecida, com profunda anemia, polipnéia ao menor esfôrço, sôpro anêmico e edemas discretos. 0 exame de fézes nessa ocasião revelou "fantástica infestação por ancylostoma",

- Trabalho apresentado, em parte, à Associaçāc Paulista de Medicina, Departamento de Higiene e Medicina Tropical, em 4-5-1949. 
encontrando-se grande número de ovos por campo microscópico, a esmo. Infelizmente não foram publicados os exames hematológicos, não havendo também nenhuma referência quanto ao quadro leucocitário. Comentando êsse caso, Martinho da Rocha Jr. diz: "não era um caso banal. Tratava-se de uma infestação em massa, uma só vez, por via cutânea, em 15 a 20 minutos!!".

Deve-se, entretanto, a Ashford, Payne e Payne ${ }^{3-4}$, um melhor conhecimento dessa forma aguda da ancilostomose e particularmente em relação à fase larvá. ria da infecção.

Os nossos dois pacientes (vide adiante) reproduzem de tal forma, além de outros pontos, os aspectos clínicos e hematológicos descritos nos trabalhos de Ashford, Payne e Payne, que julgamos de bom alvitre, para facilidade de exposição, sumariar brevemente as observações e interpretaçóes dadas por aqueles autores aos seus próprios casos. Recomendamos, porém, aos interessados a leitura, na integra, dos trabalhos mencionados.

As observações de Ashford, Payne e Payne dizem respeito a 7 indivíduos que foram cuidadosamente estudados, clínica e hematològicamente, durante cêrca de um ano, desde o início dos sintomas. Eram 7 pessoas pertencentes à classe social favorecida, de várias idades, e que adquiriram a ancílostomose durante um banho de mar, fato sem dúvida digno de nota, numa praia nas proximidades de Luquillo, Porto Rico.

$\mathrm{O}$ quadro clínico da forma aguda da ancilostomose, segundo a observação dos autores citados, resume-se em manifestações cutâneas, seguidas de sintomas desagradáveis na garganta, às vezes acompanhados de sinais de bronquite; astenia; dores epigástricas, a princípio sob a forma de cólicas, depois contínuas; diarréia com fézes sanguinolentas e fétidas; febre que em certos casos pode ser elevada e de caráter intermitente, geralmente, porém, de haixa intensidade; anemia hipocrômica, hiperleucocitose e hipereosinofilia. Descrevendo com maiores minúcias os diversos sintomas do quadro clínico, notamos que as manifestaçóes cutâneas são caracterizadas por intenso prurido, que incomoda sèriamente os pacientes, perturbando seu sono, sem que se observe na pele qualquer sinal de irritação, ou então apenas sinais como de picadas. Estes sintomas aparecem imediatamente em seguida à penetração das larvas, sua intensidade dependendo do número de larvas invasoras. $O$ prurido dura geralmente uma semana. Dos casos de Ashford e colaboradores só um paciente não se queixou de prurido cutâneo, que nos outros era presente, em intensidade variável. Já nos últimos dias ou logo em seguida ao desaparecimento do prurido, surgem os sintomas desagradáveis ao nível da faringe e laringe, apresentando os pacientes sensação de res. friado, com desconforto ou dor ao engolir ou falar, como se tivessem um catarro prêso na garganta sem conseguir eliminá-lo. Também, após uma semana ou pouco mais êsses sintomas desaparecem, para dar lugar entāo, a queixa de dor epigástrica, de intensidade variável, que pode ser muito intensa, sobrevindo em seguida evacuaçôes diarrẻicas. A diarréia é caracterizada por fézes escuras, geralmente muito fétidas, pela presença de sangue, muco ou material putrefeito. Em todos os pacientes de Ashford e colaboradores, exceto dois, as fézes continham sangue macroscòpicamente e em todos a presença de sangue foi verificada microscòpicamente ou por meio de reações químicas. Em um caso, as hemorragias intestinais foram tão profusas que puseram em risco a vida do paciente, que foi salva à custa de repetidas transfusões de sangue. A diarréia apareceu nestes casos de 2 a 4 semanas a partir da infecção. Todos os pacientes observados quei. 
xavam-se de astenia pronunciada e progressiva, acompanhada de sintomas denunciadores de anemia (palidez, cansaço, taquicardia, etc.) e mostravam ainda emagrecimento e febre com os caracteres já assinalados.

Muito mais interessantes e importantes foram as modificações sanguíneas observadas. Ocorre anemia de grau variável, podendo ser entretanto muito intensa a queda do número de eritrócitos e a redução da taxa de hemoglobina. As curvas de Price-Jones determinadas nestes pacientes revelaram-se normais ou com tendência à microcitose. No quadro leucocitário há uma leucocitose importante com elevada e característica eosinofilia. A hiperleucocitose atinge seu máximo dentro dos 3 primeiros meses da infecção aguda; depois os leucócitos tendem a diminuir lenta e progressivamente até os valores normais ou quase normais. $O$ mesmo acontece com referência aos eosinófilos. Na tabela abaixo, retirada de um trabalho de Ashford, Payne e Payne ${ }^{4}$, verifica-se exatamente o que ocorre no quadro sanguíneo, dando-nos uma idéia das cifras que podem atingir nestes casos os leucócitos e eosinófilos, e os valores alcançados pelos eritrócitos e hemoglobina. Note-se que êstes pacientes foram examinados do ponto de vista hematológico repetidamente durante quase um ano; a princípio as contagens foram feitas diàriamente, depois com 2 ou 3 dias de intervalo e por íltimo cada uma ou duas semanas. Os valores registrados no quadro abaixo (n. ${ }^{\circ}$ ) para cada

QUADRO N.o 1

\section{QUADRO HEMATOLóGICC}

(Observações de Ashford, Payne e Payne, J.A.M.A., vol. 101, n, 11, setembro de 1933, p. 846 )

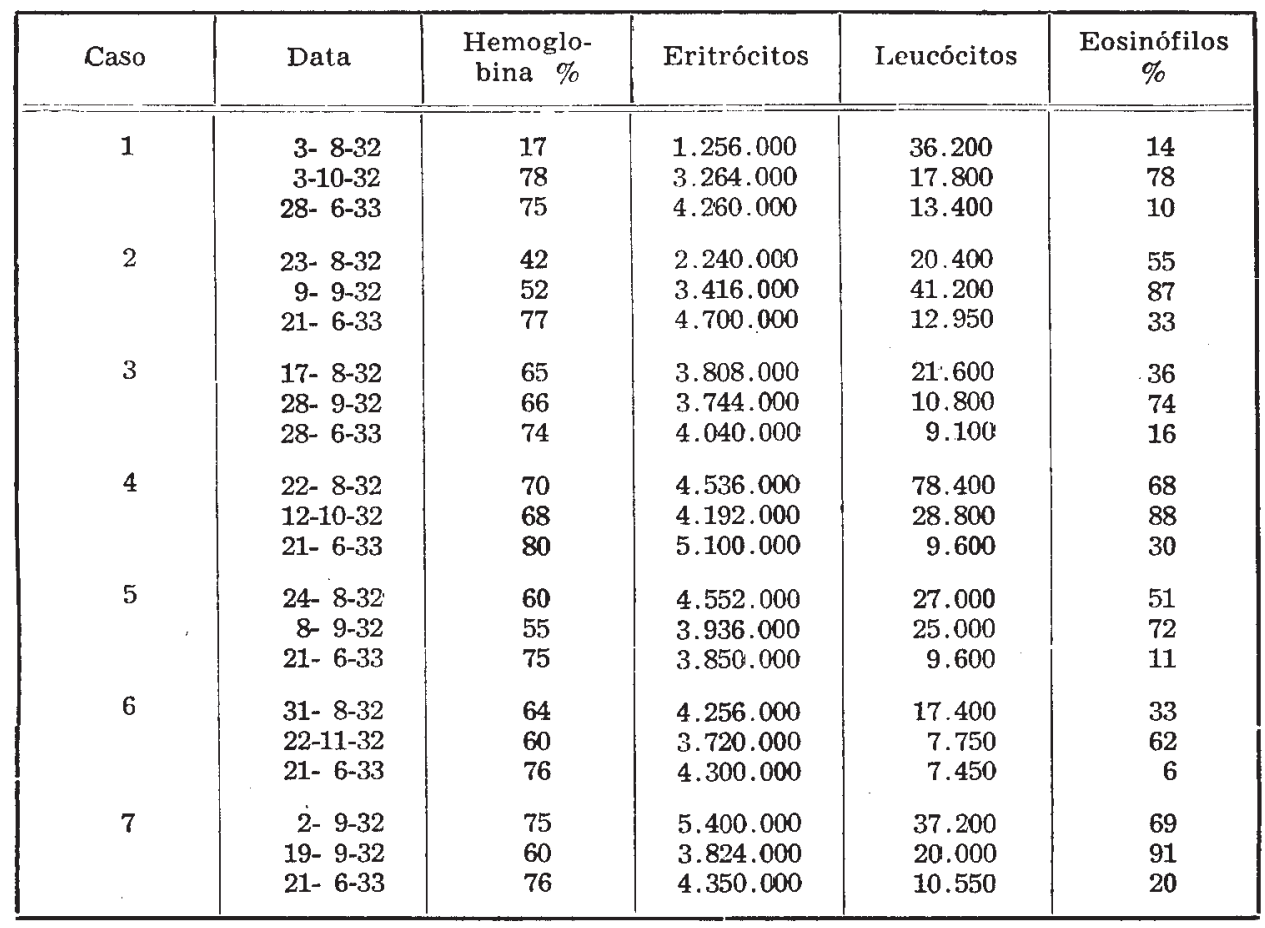


um dos sete pacientes referem-se a três épocas diferentes: quando o paciente foi visto pela primeira vez, quando a eosinofilia atingiu o mais alto valor e quando o paciente foi examinado pela última vez.

Os casos também foram acompanhados com contagens de ovos nas fézes antes e após a administração do tratamento antihelmíntico, e os vermes eliminados foram contados durante o período de observação.

Um fato digno de nota é que nestes casos os vermes identificados eram $A n$. cylostoma duodenale, muito embora em Porto Rico a ocorrência dêste nematóide seja considerada pouco frequente ou mesmo rara. Para darmos uma impressão do grau de parasitismo dêstes casos, copiamos do trabalho de Ashford e colaboradores ${ }^{4}$ o quadro seguinte $\left(n \cdot{ }^{\circ} 2\right)$, onde são indicados o número de vezes que os antihelmínticos foram administrados e o número de vermes eliminados, espontâneamente ou após a medicação.

QUADRO N.02

TRATAMENTO E RESULTADOS

(Ashford, Payne e Payne - J.A.M.A., 1933)

\begin{tabular}{|c|c|c|c|c|c|}
\hline \multirow{2}{*}{ Caso } & \multicolumn{2}{|c|}{ N.o de administração de } & $\begin{array}{c}\text { Vermes eli- } \\
\text { minados es- } \\
\text { pontânea- } \\
\text { mente }\end{array}$ & $\begin{array}{c}\text { Total de ver- } \\
\text { mes expul- } \\
\text { sos }\end{array}$ & $\begin{array}{c}\text { Lucro no pê- } \\
\text { so sob trata- } \\
\text { mento (em } \\
\text { libras) }\end{array}$ \\
\hline \hline 1 & 4 & 4 & 64 & 1.439 & 27.75 \\
2 & 2 & 5 & 32 & 614 & 42.5 \\
3 & 3 & 3 & 1 & 64 & 6. \\
4 & 3 & 3 & 9 & 125 & 36.5 \\
5 & 1 & 2 & 8 & 59 & 23.5 \\
6 & 1 & 2 & 0 & 21 & 4.75 (perda) \\
7 & 1 & 2 & 0 & 7 & 5. \\
\hline
\end{tabular}

Verifica-se que, em alguns dos pacientes, o número de helmintos foi muito pequeno. Relacionando êstes resultados ao quadro clínico apresentado pelos seus 7 pacientes, Ashford, Payne e Payne subdividiram seus casos de infecção aguda ancilostomótica em dois grupos, a saber: $10^{\circ}$, aquêles nos quais um número suficiente de larvas completou seu ciclo evolutivo atingindo o intestino; aí fixados os vermes podem determinar, pela sucção ou erosão da mucosa, o aparecimento de perdas hemorrágicas mais ou menos graves. Além das larvas que completaram o seu ciclo permaneceriam nestes casos uma população desconhecida de larvas errantes nos tecidos; $2 .^{\circ}$, aquêles nos quais a maior parte das larvas não conseguiu completar o seu ciclo e ficou errante nos tecidos do hospedador, não afetando nesta eventualidade materialmente a sintomatologia. Com efeito, esta distinção parece justificada em vista do fato de que os sintomas clínicos, excetuados os decorrentes da espoliação sanguínea, são os mesmos nos dois grupos 
de pacientes, tanto naqueles que expulsaram um número apreciável de vermes (casos 1 e 2 dos AA.) como naqueles em que o número de parasitos expulsos foi muito pequeno (caso 7 dos AA.).

Realmente, salvo a espoliação sanguínea ocasionada pelas picadas e sucção determinada pelo grande número de vermes chegados ao intestino, e traduzindo-se no quadro clínico e hematológico pela gravidade com que se pode revestir a anemia e pelo caráter sanguinolento das evacuações, os dois grupos de casos se assemelham quanto aos demais sintomas e particularmente quanto à leucocitose e à eosinofilia sanguínea. Tanto é assim que a eliminação dos vermes promove uma subida do número de eritrócitos e uma melhora da taxa de hemoglobina comparável à dos casos que constituem o $2 .^{\circ}$ grupo, isto é, aquêles em que as larvas não atingem a localização intestinal ou só o fazem em número muito pequeno.

Expulsos os vermes pela medicação apropriada. os casos do primeiro grupo acima referidos passam a se comportar, com relaçãc ao quadro sanguíneo, como os do segundo grupo, nos quais as larvas ficam errando no organismo sem completar o seu ciclo evolutivo e alingir a localização intestinal, e que na realidade exprimem melhor a fase larvária da ancilostomose estudada minuciosamente pelos autores, e manifestando-se principalmente pela astenia, emagrecimento, anemia, febre irregular, eosinofilja acentuada, hiperleucocitose, diarréia e uma ligeira carga de vermes intestinais. "Podem realmente os helmintos ser pouco numerosos no intestino ou mesmo faltar completamente; os ovos dos parasitos serem ausentes ao exame das fezes para garantir o diagnóstico; e então só o estudo hematológico cuidadoso e a observação clínica do caso permitem sugerir uma invasão larval e uma ancilostomose frustrada" (Ashford, Payne e Payne).

Segundo ainda os autores citados, era um fato já bem conhecido a hiperleucocitose e a eosinofilia sanguínea relacionadas com a fase inicial da penetração das larvas dos ancilostomídeos através da pele. Porém o que seus casos vieram esclarecer, pondo em destaque a fase larvária da infecção ancilostomótica, é que a hiperleucocitose e a eosinofilia atingem os valores mais altos, geralmente três meses após a penetração larvária e depois da eliminação da maior parte dos vermes que atingiram os intestinos. Portanto, a leucocitose e a eosinofilia são relacionadas, da mesma forma como a eosinofilia em geral, à desintegração e absorção de proteínas heterólogas ${ }^{14}$; aos produtos de desintegração das larvas no organismo do hospedador. Assim, o máximo atingido pelos eosinófilos coincide com a maior mortalidade das larvas nos tecidos, porque as larvas errantes permanecem nos tecidos, tudo leva a crer, até à sua morte. E' considerada também a possibilidade de certos sintomas dependerem da irritação intestinal (diarréia no caso 7) provocada pela eliminação de substâncias tóxicas oriundas da desintegração das larvas mortas no organismo.

Um último fato deve ser pôsto em destaque e êste refere-se à observação assinalada por Ashford, Payne e Payne ao resultado do tratamento de seus pacientes. Conquanto êstes se julgassem curados, os autores observam que: "As a matter of fact, we do not consider any of these patients cured. All are pale, and though the majority have gained satisfactorily in weight and their freedom from symptoms indicates a decided betterment, they still have a secondary anemia and an indication of a significant larval burden in the body tissues". E note-se, essa observação foi escrita após terem os pacientes sido seguidos cuidadosamente, como dissemos, por quase um ano. 
Revendo a literatura sôbre o assunto, deparamos com uma interessante publicação de Rogers e Dammin ${ }^{16}$, datada de 1946 e versando sôbre a ancilostomose nas tropas americanas em Assam e Burma. Sob muitos aspectos os casos registrados revestiram a forma da fase larvária da infecção ancilostomótica com os característicos já referidos. Inicialmente chamam os citados autores a atenção para o fato de que os pacientes observados apresentaram um quadro clínico de ancilostomose diferente da forma clássica dessa parasitose, principalmente pela subitaneidade do seu início, a proeminência dos sintomas gastro-intestinais agudos e pela falta da anemia. Os autores basearam a sua publicação em 50 casos. Os sintomas gastro-intestinais eram predominantes no quadro clínico e constituiram a causa da internação hospitalar em mais da metade dos casos. Os sintomas digestivos começaram de algumas a muitas semanas após a chegada dêsses militares ao norte de Burma. Em muitos dêles o início foi caracterizado por náuseas, vômitos, dor abdominal e diarréia. Em outros, o início da sintomatolo. gia foi gradual, com dores abdominais em forma de cólica ou queimação após as refeições. As náuseas e os vômitos e a diarréia tendiam a desaparecer e a tornarem-se intermitentes. Dos sintomas gastro-intestinais a dor era o mais saliente e persistente. A sua séde era geralmente epigástrica, mas às vêzes localizava-se na região peri-umbilical, outras vêzes no quadrante superior, à direita ou à esquerda do abdome. A dor mostrou mais vêzes uma tendência a ser difusa do que localizada a uma determinada área. Não era acalmada pela ingestão dos alimentos; ao contrário, geralmente sobrevinha imediatamente após as refeições, sendo agravada por certos alimentos, e em especial por alimentos gordurosos, fritos, ou pela ingestão de cerveja. Em certos casos a dor epigástrica sugeria a diagnose de úlcera péptica, aparecendo intermitentemente e despertando o paciente à noite. Entretanto, o seu caráter difuso, a sua ocorrência imediatamente após as refeiçóes e a associação com diarréia permitiam diferenciar êsses casos de ancilostomose da úlcera péptica, sendo o diagnóstico definitivo estabelecido pelos resultados dos exames de fezes e radiológico. A diarréia era um sintoma rebelde. evacuando os pacientes em média 6 vêzes em 24 horas. A ausência de pus, muco e sangue foi observada sempre que a amebíase foi excluida. Também o tenesmo faltou sempre. Embora a amebíase fôsse sempre considerada no diagnóstico diferencial, o exame de fezes permitia excluíla. A anorexia foi inicialmente atribuida pelos pacientes aos alimentos de campanha, mas a modificação do regime alimentar não influiu sobre o sintoma. Im $1 / 4$ dos pacientes oliteve-se pela anamnese uma informação sugestiva de uma dermatite inicial, cuja cxata avaliação tornou-se difícil em virtude da frequente ocorrência de outras dermatoses. Nunca houve uma referência espontânea a êste respeito, mas alguns pacientes lembravam-se de ter tido erupçóes intensamente pruriginosas nas pernas e coxas após dormirem nos "foxholes". Os sintomas respiratórios atribuíveis à passagem das larvas pelos pulmões foram registrados em $70 \%$ dos pacientes. Muitos dêles descreveram uma espécie de tosse ("foxhole cough"), de que se lembravam bem, porque à noite a tosse denunciava a posição ao inimigo. Era como um resfriado profundo do peito ("deep chest cold"), sem coriza ou dor de garganta. Essa tosse persistia por uma semana e prolongava-se às vêzes por muitos meses após a última exposição às larvas dos ancílostomídeos. Ao exame físico era constante o emagrecimento, atingindo por vêzes muitos quilos. Uma febrícula $(37,2-37,8)$, que não tinha outra causa, foi observada em alguns casos. 0 exame do abdome despertava, na sua parte su- 
perior. uma sensaçāo dolorosa, em pouco mais da metade dos casos; geralmente mais de uma área abdominal era sensível. Às vêzes o fígado era palpável. Em três pacientes foram vistos surtos inexplicáveis de urticária. Uma observação clínica ilustrativa acompanha o trabalho dos autores. Em 14 pacientes as fezes de cada um foi colecionada durante 24 horas após a administração do vermífugo. e os vermes expulsos foram contados. Em 13 pacientes a média de vermes expulsos foi de 37 espécimes; no caso restante foram contados mais de 100 vermes. A carga de vermes foi considerada pequena. O Ancylostoma duodenale foi identificado em 12 dos 11 pacientes estudados. Em 2 pacientes os Ancylos. loma eslavam associados ao Necator americanus. F.m 2 pacientes só foram reconhecidos exemplares de Necator. As alteraçóes sanguíneas constituiram uma feição distintiva. Dentre elas o grau da eosinofilia. A sua descoberta foi a principal razão para o exame das fezes $\mathrm{em}$ muitos casos. A eosinofilia máxima registrada foi $70 \% \mathrm{em}$ um total de 41.000 leucócitos por $\mathrm{mm} 3$. O resultado mais comum era uma eosinofilia de $40 \%$ com cêrca de 15.000 leucócitos. As flutuações dos números tanto dos leucícitos como dos eosinófilos eram frequentes. 0 periodo mais precoce para o aparecimento da eosinofilia após a data suspeita de infecção nesses 50 pacientes foi aos 30 dias. A eosinofilia persistiu na maior parte dêles, num menor grau. durante semanas e meses, a despeito do emprêgo frequente de vermifugos. A anemia não era nem acentuada nem constante. uma taxa de hemoglobina de 12 g ou abaixo sendo presente em 6 pacientes dêste grupo. Em 3 dêles havia outras causas concomitantes possiveis para explicar a anemia. Fim 42 pacientes foi feito um estudo radiológico do intestino delgado, encontrando-se alterações em 31. Estas alterações serão descritas adiante. pois concordam com as assinaladas por Hodes e Keefer ${ }^{11}$ em casos semelhantes, conforme referiremos dentro em pouco. Rogers e Dammin. depois de considerarem as condições epidemiológicas que propiciaram a aquisição da ancilostomose por êste grupo de militares. analisam os resultados da terapêutica antihelmíntica observados durante um período de 1 a 6 meses. Em 34 pacientes examinados após a última dosa de vermífugo foram feitos exames de fezes por método de concentração. Dêstes, $20(63 \%)$, ainda mostravam ovos de Ancylostoma, apesar de já tratados duas vêzes. A eosinofilia variou consideràvelmente de contagem para contaçem, mas em geral ela diminuiu após a administração do vermífugo. () grau da eosinofilia baixou de uma média de 13.700 leucócitos com $34 \%$ de eosinófilos para 9.600 , com $21 \%$ de eosinofilos. Fim sòmente 3 pacientes a eosinofilia caiu abaixo de $4 \%$ após o tratamento.

Discutindo êstes casos, os autores concluem que. em vista dos sintomas clínicos, da eosinofilia e da presença de ovos de ancilostomos nas fezes, tratava-se de exemplos de ancilostomose aguda. Consideram vários fatôres responsáveis por esta feição particular dos seus casos, a saber:

1.') Os pacientes eram indivíduos sadios, presumivelmente isentos de parasitismo e foram expostos aos parasitos por um curto periodo de tempo. Consideram como conjetural a possibilidade de representar a sintomatologia uma manifestação alérgica local ou ser devida à irritação local produzida pelos vermes na porção alta do intestino delgado. A elevada eosinofilia faria supor uma considerável reação a proteinas estranhas. A circunstância de se tratar de um grupo de jovens adultos brancos expostos ao Ancylostoma duodenale poderia, no pensar dos AA., explicar, em grande parte, êstes casos. Eles fazem notar a des. proporção evidente entre a exuberância da sintomatologia abdominal e o peque- 
no número de vermes nestes pacientes. Pensam justificar esta discrepância atribuindo ao Ancylostoma duodenale a capacidade de provocar uma forma mais grave de ancilostomose do que o Necator americanas, e a produzir sintomas com menor número de vermes adultos.

$\left.2 .^{\circ}\right)$ Outro fator a ser considerado seria a alta incidência de moléstias intercorrentes (malária vivax, disenteria bacilar, tifo, difteria cutânea) e ferimentos de guerra.

$3^{\circ} .^{\circ}$ A situaçãó na qual a parasitose foi contraída, sob a ação das emoções do combate, das restrições dietéticas, da fadiga física, também poderia representar algum papel.

Depois de outras considerações em que os autores frizam as dificuldades às vêzes encontradas para demonstrar a presença dos ovos dos parasitas nas fezes, mesmo utilizando métodos de concentração, dizem suspeitar que a eosinofilia se manifesta antes de aparecerem os ovos nas fezes, embora não possuam dados com. probatórios a êste respeito nesta série de casos. Entre as suas conclusões, estabelecem os AA. a seguinte: "que na maior parte dos livros descreve-se a ancilostomose com um quadro dominado pela anemia e desnutrição. À luz destas observações é claro que a ancilostomose em adultos brancos e jovens possa ser uma enterite aguda antes que apareça a anemia e a desnutrição; o diagnóstico pode muitas vêzes ser suspeito clinicamente nesta fase, em base dos fenômenos descritos".

Como já aludimos anteriormente, Hodes e Keefer ${ }^{11}$ realizaram em 1945 um estudo radiológico do intestino delgado em militares com ancilostomose contraída na Província de Assam, na Índia, onde a incidência da parasitose é muito elevada. Foram examinados sob êste ponto de vista 125 indivíduos, cuja sintomatologia reproduz exatamente aquela referida por Rogers e Dammin. Todos os pacientes apresentavam ovos de ancilostomídeos nas fezes, mas os vermes adultos só foram identificados em 14 casos. Nestes o Ancylostoma duodenale foi reconhecido 8 vêzes; o Necator americanus 2 vêzes. Nos 4 outros havia associação dêsses dois nematóides. Clinicamente, êstes casos apresentavam em resumo: prurido cutâneo e dermatite ("ground itch"), que aparecem algumas horas após a infecção e duram 4 a 7 dias. Geralmente, 1 a 2 semanas após aparecia a tosse ("foxhole cough") sèca e superficial. O início dos sintomas gastro-intestinais variou de 6 a 25 semanas após a exposição; êstes eram caracterizados por náuseas, vômitos, dor abdominal e diarréia. Também uma elevação cérmica foi por vêzes registrada. A anemia era discreta, salvo em ? pacientes que pareciam altamente infectados, dada a intensidade dos sintomas. Mais da metade dos pacientes apresentava leucocitose (mais de 10.000 leucócitos por $\mathrm{mm} 3$ ); em média os leucócitos orçavam em 15.000 por $\mathrm{mm} 3$. A contagem mais elevada revelou 41.000 leucócitos com $41 \%$ de eosinófilos. Em 68 pacientes observados hematológicamente, 8 apresentavam menos de $10 \%$ de eosinófilos; 30 tinham de 11 a $30 \%$ de eosinófilos e 30 tinham mais de $30 \%$ de eosinófilos. O maior grau de eosinofilia registrado foi $80 \%$ com 25.000 leucócitos por mm3. A eosinofilia estava em relação com a intensidade dos sintomas e com as modificaçóes radiológicas encontradas (vide adiante).

Com as melhoras obtidas os eosinófilos diminuiam. Foram examinados radiològicamente 125 pacientes, dos quais $60 \%$ mostraram alteraçóes radiológicas do intestino delgado. Estas alterações radiológicas foram observadas a partir de 
um mês após a infecção parasitária. Hodes e Keefer descrevem minuciosamente as alterações intestinais encontradas em seus pacientes, as quais assemelharam-se às encontradas em casos de avitaminose crônica. Estas alterações radiológicas coincidiam com aquelas denominadas por Golden uma "função motora desordenada" (disordered motor function). Elas são caracterizadas pelo exagêro das contrações segmentares e peristálticas, acompanhadas por distorção do relêvo da mucosa. As anormalidades radiológicas aparecem primeiramente na parte proximal do jejuno, e daí se propagam para o duodeno distal, resto do jejuno (jejuno distal) e todo o íleo. Procurando uma causa para essas alterações, Hodes e Keefer inclinam-se a admitir como possível uma lesão do sistema nervoso intramural do intestino delgado. Atribuem aos dentes de que é provida a cápsula bucal dos Ancylostoma duodenale, a possibilidade de ferir a mucosa intestinal, atingindo as células e fibrilas nervosas dos plexos intestinais subseroso de Auerbach e muscular de Meissner.

A nós nos parece muito duvidosa essa possibilidade, pois os próprios autores reconhecem que a mera presença dos helmintos não pode ser responsabilizada pelas aludidas alterações, porque estas persistem após a eliminação dos parasitas sob a ação dos vermifugos, e porque semelhantes modificações radiológicas faltam em $40 \%$ dos pacientes com ancilostomose comprovada. Eles assinalam que em alguns casos as alterações radiológicas persistcm durante meses, quando os pacientes se mostram clinicamente bem; em outros casos as melhoras ocorrem precocemente.

Em 1947 Whitehouse ${ }^{19}$ registrou 2 observaçóes de ancilostomose com eosinofilia maciça e leucocitose, e cuja sintomatologia clínica, apresentada pelos pacientes, reproduzia exatamente o quadro da ancilostomose aguda. Em ambos dominava clinicamente os sintomas digestivos; num caso a diarréia foi intensa, com cólicas abdominais e febre que durou 3 semanas. No outro, o sintoma mais saliente foi a epigastralgia; também tinha febrícula, que durou 5 dias. Astenia e anemia eram presentes em ambos os casos. O emagrecimento foi acentuado nos 2 pacientes. Em ambos o exame de fezes demonstrou ovos de ancilostomídeos e foi positivo para sangue oculto. Num dêles a anamnese apurou a existéncia pregressa de dermatite ancilostomótica em consequência à penetração das larvas através da pele da planta dos pés, em virtude de ter o paciente (um soldado japonês) gasto os seus sapatos durante a campanha e permancido algum tempo descalço. Os quadros hematológicos de ambos os casos são superponíveis. Em ambos verificou-se redução do número de eritrócitos e da hemoglobina (eritrócitos 3.200 .000 por $\mathrm{mm} 3$ e hemoglohina $9.4 \mathrm{~g}$; eritrócitos 3.700 .000 e hemoglobina 9.3, respectivamente, num e noutro caso). Nos dois casos notou-se leucocitose e cosinofilia. Num dos pacientes existiam 18.350 leucócitos por mm3 e $69 \%$ de eosinofilos. Duas semanas depois os leucócitos alcançaram 32.900 e os eosinófilos 71\%. Depois de 3 semanas de aplicação de vários antihelmínticos ainda havia anemia e eosinofilia. No segundo paciente a primeira contagem revelou 52.800 leucócitos com $66 \%$ de eosinófilos; depois os leucócitos baixaram para $44.150 \mathrm{~mm} 3 \mathrm{e}$ as eosinófilos para $59 \%$.

$\mathrm{E}^{\prime}$ interessante referir que num gráfico anexo ao trabalho do autor verifica-se a flutuação dos eosinófilos e a subida da taxa dêstes granulócitos, nos 2 casos estudados, após a administração da primeira dose de antihelmíntico, baixando, gradualmente, em seguida, sem, contudo, atingir os valores normais durante o período de observação (56 dias). 
De acôrdo com o que expusemos, vemos que os casos de Rogers e Dammin, os de Hodes e Keefer e os de Whitehouse são comparáveis aos descritos por Ashford e colaboradores. Excluida a anemia, que foi módica ou inexistente nestes casos, e as modificações radiológicas que não foram estudadas nos casos de Ashford, vemos que os sintomas clínicos e a sua sequência foram os mesmos em todos êles. As observações de Rogers e Dammin, de Hodes e Keefer e as de Whitehouse exemplificam bem os casos do $2 .^{\circ}$ grupo de Ashford e colaboradores, ou seja aquêles nos quais domina verdadeiramente a fase larvária da infecção ancilostomótica.

Consideraremos por fim algumas observaçōes que têm o valor de um argumento experimental em conexão com o estudo da fase larvária da infecção ancilostomótica. Tais observações dizem respeito a uma modalidade de tratamento em pacientes com policitemia, pela penetração de larvas de Ancylostoma duodenale, visando um benéfico efeito anemiante, determinado pela infecção experimental.

Êste método terapêutico foi proposto primeiramente por Duvoir e colaboradores $^{8}$, que publicaram em 1940 a observação de um caso referente a uma senhora, porladora de poliglobulia e hipertensão arterial, que havia sofrido uma hemiplegia direita e uma crise de infarto pulmonar, e que foi tratada pela infecção experimental com 300 larvas estrongilóides de $A$. duodenale. No dia seguinte a paciente apresentou pápulas róseas no local da pele (coxa) onde penetraram as larvas. Não foram observadas manifestaçôes respiratórias atribuíveis ao trânsito pulmonar dos parasitos. A cifra de eritrócitos reduziu-se de 8.250 .000 glóbulos a 3.570 .000 por $\mathrm{mm} 3$ e a taxa de hemoglobina baixou para $80 \%$. No curso dos primeiros meses verificou-se hiperleucocitose, que se manteve nas proximidades de 40.000 leucócitos por $\mathrm{mm} 3$, sendo que a eosinofilia atingiu $75 \%$.

Duvoir e Brumpt (1944-1945) ${ }^{9}$, a propósito de 7 casos de policitemia tratados pela ancilostomose provocada, descreveram a evolução da parasitose nos pacientes desde a penetração cutânea das larvas até à fixação dos vermes adultos nos intestinos. Os A.A. descrevem vários tipos de manifestações cutâneas provocadas pela penetração das larvas, e referem-se à imigração destas através dos pulmões, que dizem ter-se operado nestes casos silenciosamente (inclusive à radiologia pulmonar). Apenas num caso o doente queixou-se de dor retroesternal e tosse, seguidas de rouquidão e disfagia, o que foi interpretado como devido à passagem das larvas pela traquéia e esôfago. Em quase todos os casos a presença dos vermes no duodeno se traduziu por dores epigástricas profundas, sem relação com a ingestão dos alimentos, e dando a impressão de queimação, picadas ou torção. Em 5 dos 7 casos, esta epigastralgia foi acompanhada de diarréia. Estes sintomas iniciaram-se no fim de 4 a 6 semanas, quando os ovos do parasito surgiram nas fezes. Os sintomas referidos duraram algumas semanas, desaparecendo depois, e foram atribuidos a uma duodenite aguda (radiològicamente, num caso verificou-se a existência de edema da mucosa da 3. ${ }^{\mathrm{a}}$ porção do duodeno e $1 .^{\mathrm{a}}$ alça do jejuno, que estavam dilatadas). A pesquisa de sangue oculto foi feita diàriamente em 2 casos, nos quais se positivou, respectivamente, no $23 .^{\circ}$ e no $400^{\circ}$ dia. Em nenhum paciente foi observado melena. Os ovos do parasito foram encontrados no $40 .^{\circ}$ e $39 .^{\circ}$ dias.

Quanto às moditicações leucocitárias, houve apenas referência num caso, que mostrou uma hiperleucocitose (47.000 leucócitos por $\mathrm{mm} 3$ ) com $66 \%$ de eosinófilos. 0 máximo de leucocitose e eosinofilia ocorreram no $3 .^{\circ}$ mês, coincidindo 
com os valores mais baixos para os eritrócitos. Nas infecções antigas os eosinó. filos ainda orçavam em $10 \%$ no fim de um ano de observação. Nos casos sujeitos a infecções provocadas o grau de leucocitose e eosinofilia, como a baixa dos eritrócitos, era sempre menor que na infecção original.

Terminam os A.A. o seu trabalho considerando as melhoras do quadro clí. nico dos seus pacientes e as vantagens e inocuidade do processo terapêutico utilizado, cuja única desvantagem consiste no aparecimento frequente de duodenite, fàcilmente, segundo êles, remediada.

Em 1945 Brumpt $^{5}$ referiu-se, em uma aula, a 8 casos de policitemia tratados pelo mesmo processo (penetração de 400 a 700 larvas por via cutânea). Aludiu aos sintomas de epigastralgia e diarréia consequentes à infecção aguda ancilostomótica, e descreveu os resultados obtidos sôbre a policitemia. Segundo suas observações, no fim do $10^{\circ}$ mês os eritrócitos diminuem progressivamente, atingem 4.000 .000 por $\mathrm{mm} 3$. No fim do $3 .^{\circ}$ mês e por volta do $6 .^{\circ}$ mês chegam aos valores próximos do normal. Os leucócitos atingem um máximo de 40.000 a 60.000 glóbulos por $\mathrm{mm} 3$ no fim do $3 .^{\circ}$ mês, e então diminuem. Esta leucocitose é eosinofílica, pois os eosinófilos compreendem $75 \%$ dos leucócitos no $3 .^{\circ}$ mês, $20 \%$ no $60^{\circ}$ mês e $15 \%$ no fim de um ano.

Ao lado destas modificações verificou-se melhoras clínicas apreciáveis e duradouras, dos sintomas dependentes da policitemia.

Mais recentemente, Nagaty e Zanaty ${ }^{12}$ publicaram a observação de um caso de policitemia vera estudado por êles durante 21 meses e tratado pela ancilostomose provocada, confirmando os estudos anteriormente citados. A observação detalhada do caso é interessante, porque mostra a sequência dos sintomas determinados pela fase larvária da infecção ancilostomótica. E' êste o caso, em resumo: Um homem de 55 anos era portador de uma policitemia vera bem caracterizada. O paciente foi submetido a vários tratamentos, resolvendo, por fim, os autores aplicar o mélodo terapêutico proposto por Duvoir e colaboradores. $O$ doente foi infectado da $1 .^{\mathrm{a}}$ vez com 150 larvas de $A$. duodenale e depois com mais 250 larvas. Após as duas aplicaçóes surgiu a dermatite local e dois meses depois da $1 .^{a}$ deposição cutânea das larvas apareceram sintomas de traqueíte e diarréia. O número de leucócitos, que era de 8.200 antes do tratamento, subiu para 15.000 glóbulos por mm3 e os eosinófilos passaram nessa época de $1 \%$ para $36 \%$. Foram feitas várias contagens que evidenciaram, ao lado da redução progressiva dos eritrócitos e da taxa de hemoglobina, uma persistência da lencocitose com eosinofilia. Os leucócitos atingiram 17.000 e os eosinófilos $65 \%$. Como o número de vermes, calculado pela contagem de ovos nas fezes, fôsse pequeno e houvesse tendência dos eritrócitos para se elevarem, foi o paciente reinfectado mais 3 vêzes, respectivamente com 150, 1.50 e 250 larvas. O quadro exposto no trabalho dos A.A. demonstra que no fim de 21 meses de observação os eritrócitos haviam baixado da taxa inicial de 8.000 .000 por $\mathrm{mm} 3$ para 5.000 .000 por mm3; a hemoglobina baixou de $140 \%$ para $60 \%$. Entretanto os leucócitos mantinham-se ainda em 12.000 por $\mathrm{mm} 3$ com $27 \%$ de eosinófilos. Nas várias contagens verifica-se a flutuação dos leucócitos e eosinófilos que, entretanto, mantiveram-se sempre em taxas elevadas relativamente aos valores iniciais. Quando o paciente foi visto pela última vez os sintomas clínicos da policitemia tinham melhorado consideràvelmente. Os A.A. referem, sem maiores comentários, que o número de larvas utilizadas na infecção experimental foi muito maior que o número de vermes albergados pelo paciente, avaliados pelas contagens de 
ovos nas fezes, o que êles atribuem a dois fatôres: que nem tôdas as larvas depositadas na pele tenham penetrado, e que nem tôdas as que penetraram conseguiram atingir o intestino do hospedador.

E' curioso mencionar que tanto nos trabalhos de Duvoir e colaboradores, de Hodes e Keefer, como nos de Rogers e Dammin. Whitehouse, Nagaty e Zanaty, acima citados, não se encontre neithuma referência às observações fundamentais de Ashford, Payne e Payne, embora em todos se verifique a confirmação dos fatos por êstes últimos estudados tão minuciosamente.

Em conclusão, à luz dessas observações e das nossas próprias adiante transcritas, parece lícito concluir que os nossos atuais conceitos sôbre a anemia ancilostomótica devem ser revistos, pelo menos em relação à fase larvária da infecção ancilostomótica.

Aliás, W. Oswaldo Cruz ${ }^{13}$, com a sua grande autoridade no assunto, nos ensina que: "The cases which today constitute the acute hookworm disease, owing to their rareness and characteristic features, should be studied separately, as a disease of an exclusively helminthic origin, the transient symptomatology of which depends exclusively on the cycle of helminthic development within the body of its host. Only in these cases we may properly speak of "ancylostomiasis" or hookworm disease".

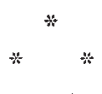

Tendo em vista o que foi exposto, julgamos os dois casos seguintes dignos de registro, assim como alguns comentários, que serão feitos após o relalo das respectivas observações.

Caso n. ${ }^{\circ} 1$ - Em 20-12-1948 um de nós (J.A.M.) foi consultado pelo menor L.A.T.L., de 9 anos e meio de idade, branco, brasileiro, escolar, residente nesta Capital e que se apresentou à consulta acompanhado de seus pais, que colaboraram na obtenção desta amnese, seja confirmando as informaçóes do paciente, seja esclarecendo-as. Foi apurado que L.A.T.L., em companhia de seus pais, de uma sua irmã de 16 anos, de um primo e de dois tios e respectivos filhos, em número de 3 , no dia 15 de novembro do mesmo ano, esteve em Santos e dali foi a São Vicente, permanecendo a manhã tôda na Praia Grande. Lá o paciente esteve brincando tôda a manhã na areia, em folguedos próprios da idade e do local, até que à tarde, por volta das 14 horas, êle começou a sentir intenso prurido em todo o corpo. O prurido era tão incômodo e tornou-se de tal modo insuportável que seus pais resolveram voltar nessa mesma tarde para São Paulo. A viagem, que foi feita de automóvel, teve que ser interrompida várias vêzes, na tentativa de procurar aliviar o prurido (fricções com álcool, aplicação de talco, etc.), sem nenhum resultado. $\mathrm{Na}$ pele apareceu uma espécie de "grosseira", principalmente nos membros inferiores. À noite o paciente não conseguiu dormir porque o prurido the impedia o sono, dizendo sua mãe que nessa noite o prurido foi "alucinante". Com o passar dos dias, a "grosseira" referida desapareceu e no fim de uma semana o prurido, que paulatinamente foi diminuindo de intensidade, também havia desaparecido. A partir de então o paciente começou a apresentar tosse sêca, com sensação desagradável e indefinivel na garganta, e a sua voz se tornou rouca. Procurou um especialis- 
ta em olorrinolaringologia. que fez o diagnóstico de laringile e recomendou. como tratamento para o caso. inalaçōes de Perubore e 3 doses de Penicilina óleocera. 300.000 u. Este episódio de tosse e rouquidão durou cêrca de 8 dias. Sua mãe notou. entretailo. que o paciente vinha ùltimamente se enfraquecendo. mostrando-se sem ánimo para os estudos e mesmo para os brinquedos, cansando-se facilmente e procurando estar a maior parte do teinjo em repouso. Mostrou-se ao mesmo tempo inapetente e foi ficando pálido. palidez que cada dia mais se acentuava. Nos 8 dias que precederan a consulta começou o paciente a se queixar de dor epigástrica forte, como cólica, durando a dor muitas horas; esta dor foi se inlensificando. assumindo tipo contínuo. não sendo aliviada pelo repouso. nem influenciada diretamente pela alimentação nem por qualquer posição no leito. A noile a dor interrompia o sono. Foi chamado um pediatra que diagnosticou apendicite $\mathrm{e}$ indicou a intervenção cirúrgica. O paciente foi então examinado por um cirurgião que discordou do diagnóstico e solicitou um exame hematológico (vide quadro 3. 13-12-48). Fim vista do resultado do exame hematológico (eosinofilia de $41,5 \%$ ), o cirurgião soliciton exame parasitológico das fezes (vide quadro 1). que foi negativo mesmo após sua repeticão, exame de urina, que não trouxe nenhum esclarecimento (vide adiante). Fm vista dêstes resultados o paciente foi encaminhado a um de nós, como já foi dito. Nos antecedentes pessoais, além das moléstias peculiares à infânria, nada mais foi verificado digno de nota. O paciente, que é filho de cunceituado advogado, sempre gozou saúde até a presente moléstia. Nos antecedentes familiares, nada de interêsse a ser registrado. Dos acompanhartes de nosso ob. servado ao passeio à Praia Grande no dia em que êle se infectou apenas soubemos que seu primo também apresentou exame de fezes positivo para ovos de ancilostomídeo, mas a parasitose não assumiu no seu caso nenhum aspecto insólito. O exame clínico nessa ocasião revelou tratar-se de um jovem bem cons. tituido, emagrecido (pêso 27k,400), afebril (temp. 36), com palidez pronuncia. da da pele e descoramento das mucosas visiveis. Na pele não existia senão al. gumas pequenas cicatrizes lenticulares, numerosas principalmente nos membros unferiores. Dos gânglios, só os inguinais eram palpáveis, dos dois lados, sendo pouco numerosos e de pequeno tamanho. Taquicardia 1100 pulsações por minuto), P.A. 90-60. () exame do ajarelho respiratório resultou negativo, 0 exame do coração só revelou taquicardia, sendo as bulhas bem hatidas e com caracteres normais. () exame do abdome nada de particular revelou à inspeção a não ser ligeiro abaulamento do ventre (ausência de circulação colateral, edem:). Vão havia sinais de ascite. Não havia resistência à palpação, mas a região epigástrica era muito sensível, mesmo à palpação superficial. O fígado e o haço eram impalpáveis. Foi pedido um exame radiológico do tórax, cujo resultado foi o seguinte: transparência pleuropulmonar normal. Foram solicitados também novo exame de fezes (vide quadro 4) e uma contagem global e especifica (vide quadro 3, 24-12-48). Em vista dêstes resultados, concluimos que se tratava de um caso de ancilostomose aguda e indicamos: a) repouso relativo melhorar a alimentação do paciente, que vinha sendo muito reduzida, em parte devido à inapetência e em parte por indicação médica anterior; b) medicação antianêmica: sulfato ferroso $0,20,3$ vêzes ao dia e polivitaminas (Vimagna); c) aplicações de calor local (bôlsa d'água quente) no epigástrio e medicação antiespasmódica (beladona). Depois de uma semana fomos chamados para ver o paciente em seu domicílio, sendo ali informados que seu estado se agravara. 


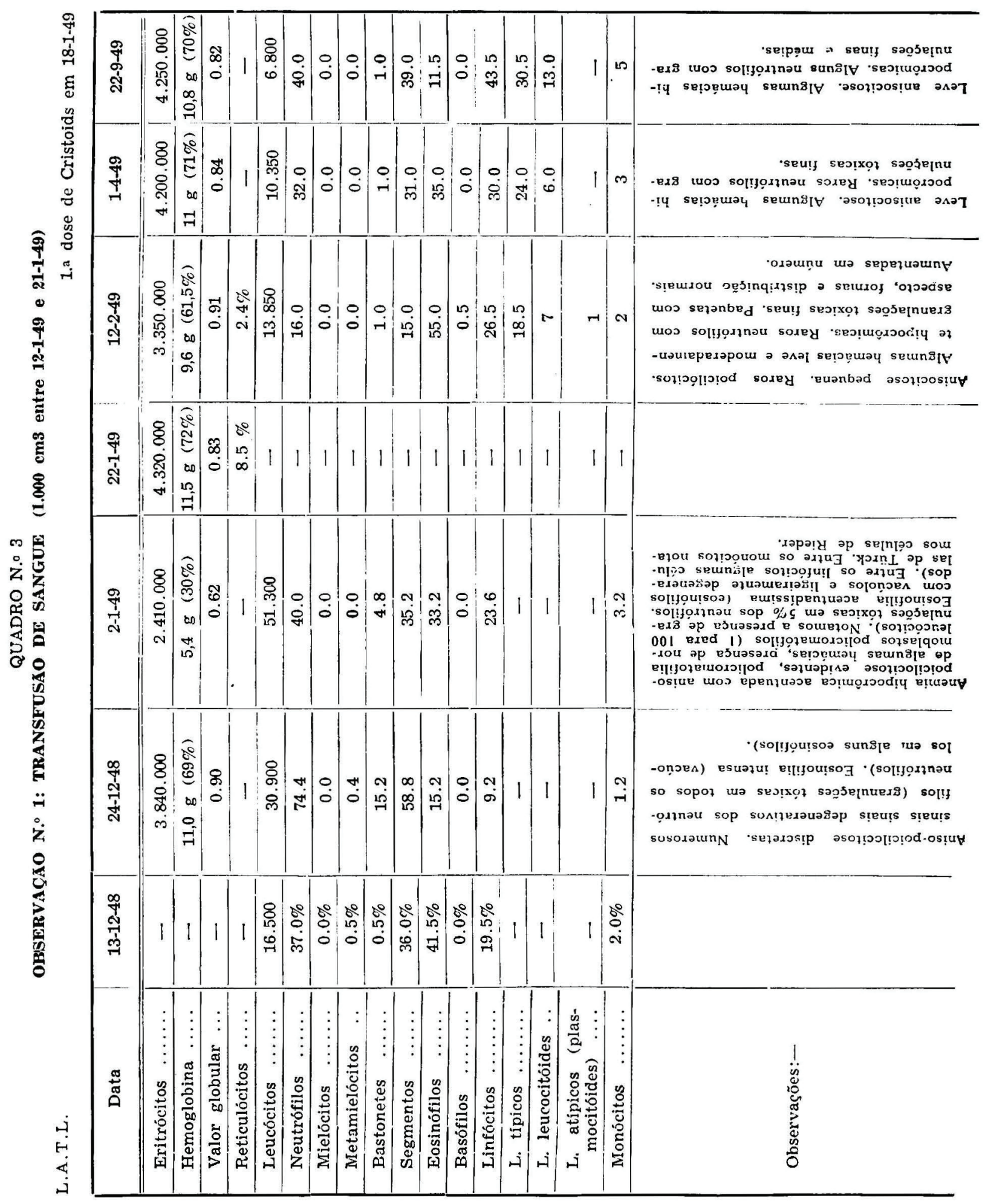


As dores abdominais eram intensas, contínuas; o paciente passava mal a noite, com as dores; os alimentos não eram tolerados, sendo parcialmente rejeitados, com vômitos. Estes eram precedidos de náuseas. Sobreveio depois diarréia líquida, extremamente fétida, sendo as evacuações pouco frequentes, muito escuras, sanguinolentas. Ao exame verificamos que a palidez se tornara extrema, as mucosas ainda mais descoradas que anteriormente; o menino permanecia deitado a maior parte do dia, sem ânimo para se levantar, e a única posição que lhe dava um pouco de alívio era a posição de cócoras. A temperatura, tomada diàriamente a nosso pedido, registrava à tarde, febrícula de $37,2-37,3$. O exame físico, além dos sinais de evidente anemia, não mostraya outras alteraçōes. 0 baço e o fígado permaneciam impalpáveis. A região epigástrica era muito sensivel à palpação superficial. Havia queilose nítida em ambos os cantos da bôca. P.A. 90-50. Pedimos novo exame hematológico (12-1-49) e em vista do seu resultado indicamos transfusōes sanguíneas, e entre esta data e 21-1-49 (quadros 3 e 4) o paciente recebeu 1 litro de sangue total. Quando já havia recebido 700 cm3 de sangue e as suas condições demonstraram grande melhora, em 18-1-49 foram administradas 4 cápsulas de Cristoids (vide quad̄os 3 e 4 ), tendo durante os 3 dias anteriores feito, em amostra de cada dia, uma contagem de ovos pelo método de Stoll (vide quadro 4). Os vermes eliminados foram contados e identificados como Ancylostoma duodenale. Muitos vermes estavam desintegra. dos e não puderam ser contados. Durante a observação as fezes eram enviadas diàriamente ao Departamento de Parasitologia da Faculdade de Higiene para recuperação e identificação dos vermes (quadro 4). Em 24-1-49 o paciente apresentava nítidas melhoras clínicas e hematológicas (vide quadro 3). A dor epigástrica diminuiu consideràvelmente de intensidade, quase não incomodando mais o paciente. O seu apetite melhorou muito. Os alimentos que, antes só eram ingeridos à custa de insistentes pedidos de sua mãe, eram agora reclamados. As côres da pele e das mucosas apresentavam-se muito melhores. O paciente foi submetido a outras doses repetidas de Cristoids (vide quadro 4), sendo suas fezes examinadas frequentemente. $O$ pêso oscilou da seguinte maneira: em 20-12. $49-27,400$; em 24-1-49 - 26,400; em 9-2-49 - 26,800 e em 31-3-49 28,500. Depois de mais 5 doses de Cristoids o exame de fezes ainda persistia positivo para ovos de $A$. duodenale, mas o quadro sanguíneo melhorara, reduzindo-se a anemia e a leucocitose, sendo, entretanto, nítida ainda a eosinofilia. Os sintomas clínicos desapareceram, não se queixou mais de dor epigástrica, e o paciente voltou à escola. Durante todo o periodo de observação o paciente foi submetido a tratamento ferruginoso (sulfato ferroso) e polivitamínico, que foi suspenso em 31-3-49.

Caso n. 2 - Em 25-3-1949 um de nós (J.A.M.) foi chamado para ver a menor V.M.B.L., de 10 anos de idade, brasileira, branca, escolar e residente num bairro aristocrático desta Capital, contando-nos sua mãe o seguinte: Que em fins de dezembro de 1948, no Guarujá, onde fôra a paciente passar as férias escolares e onde costumava brincar descalça na areia da praia, começou certo dia a sentir prurido na planta de um dos pés. A mãe da menina notou a existência de máculas róseas como picada de inseto no local pruriginoso. Pensou que fôsse larva "migrans" porque a pequena já tivera dermatite serpiginosa anteriormente, mas observou que o aspecto desta vez era diferente, porque não havia migração das "manchas". Apesar disso fêz aplicação local de Cloretila, que já 
QUADRO N.0 4

OBSERVAÇÃO N.* 1

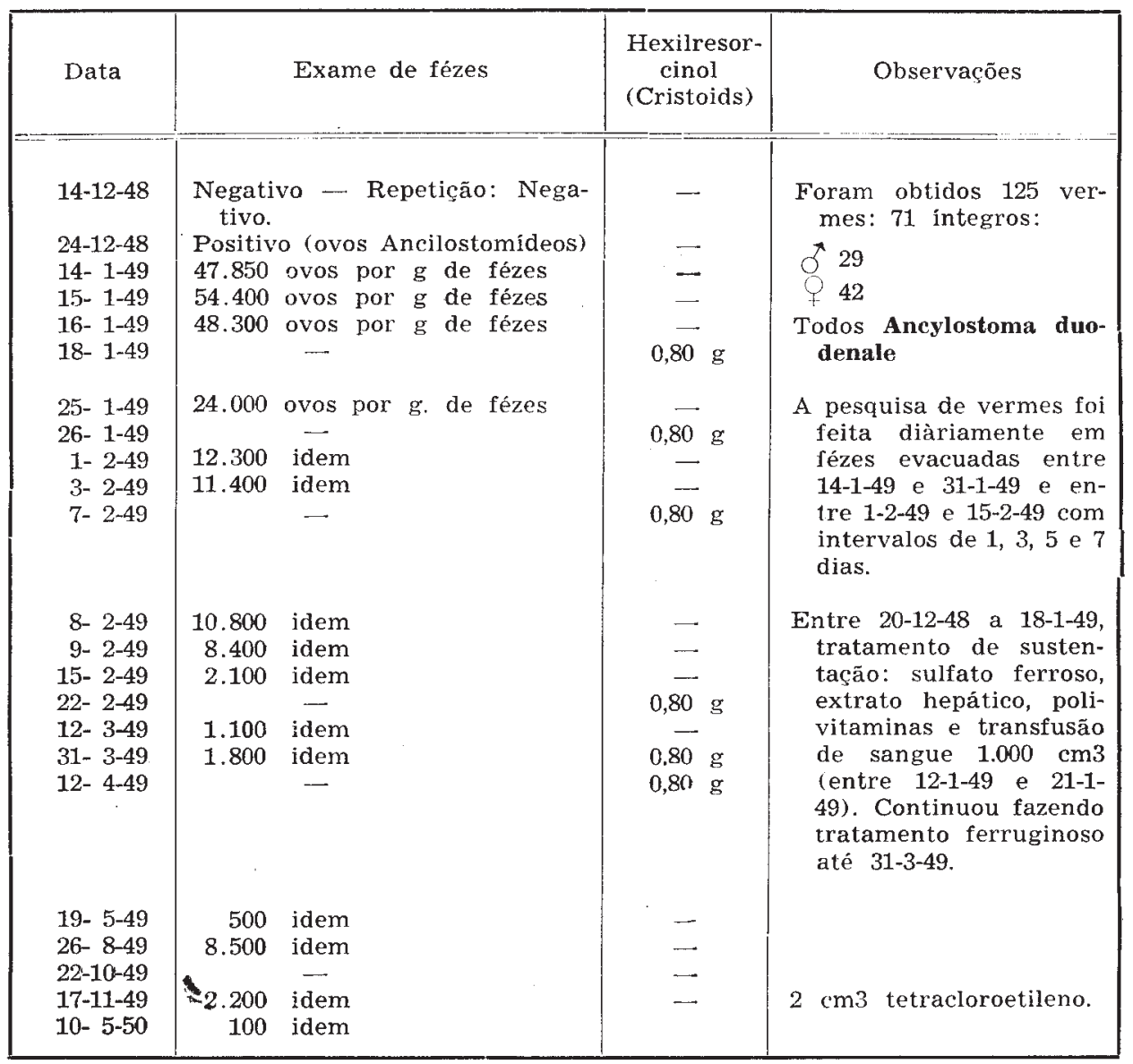

havia feito na infestação anterior, e alguns dias depois o prurido desapareceu. Sobreveio então tosse, sèca, com rouquidão da voz, sem febre, e sintomas caiarrais. Essa tosse, que apareceu 10 a 15 dias após o prurido cutâneo, persistiu até fevereiro. Por causa da rebeldia da tosse à medicação caseira a menor foi trazida a São Paulo para ser examinada pelo seu pediatra; êste diagnosticou "basite" e indicou tratamento nesse sentido. Voltando para o Guarujá continuou com tosse sêca e passou a ter dor no ventre, localizada no abdome superior. A princípio a dor era de pequena intensidade, mas com o correr dos dias tornou-se mais intensa, contínua, exacerbando-se com a ingestão de alimentos, e impedindo o sono, pois que a menina acordava à noite queixando-se de dor abdominal. Essa dor era localizada em todo o abdome superior, que era principalmente sensivel no epigástrio e região periumbilical, tanto espontâneamente como à pressão. De volta a esta Capital, como o pediatra que sempre cuidara da menina adoecera, 
e dada a insistência da dor, foi chamado para vê-la um cirurgião. Foi feito um exame hematológico nessa ocasião (10-2-1919) e diagnosticado apendicite. Co. mo a leucocitose tivesse aumentado no dia seguinte (vide quadro 5), resolveu o cirurgiāo intervir, tendo sido realizada a apendicectomia em 17-2,49. O pús-operatório decorreu sem incidentes, informando a mãe da raciente que o cirurgião dissera que o apêndice estava ligeiramente alterado e que a operação era necessária mas não urgente. Após 8 dias da operação a dor abdominal desapareceu. bem como já havia desaparecido a tosse. Findos êstes 8 dias a dor abdominal reapareceu com maior intensidade. com os mesmos caracteres e sede anteriores. Não havia náuseas nem vômitos. Azia ocasionalmente. Evacuações moles, às vêzes com sangue. Foi feito exame de fezes, tendo resultado positivo para ovos de ancilostomídeos, e um clínico chamado, indicou a administração de um vermífugo (Cristoids). Ȧ administraçấo do antihelmíntico seguiram-se 9 dias de acalmia da dor. Passado êsse tempo sobreveio nova crice dolorosa, com evacuações diarréicas e sanguinolentas. Em vista disso o clínico resolveu solicitar exames radiológicos do intestino. na suspeita de um diverticulo de Maeckel, mas foi chamado agora um outro pediatra que suspeitou tratar-se de "púrpura abdominal" e indicou como tratamento: cloreto de cálcio, coaguleno, vitamina $C$, vitamina $K$, extrato hepático e ainda, tendo em vista o resultado do exame de fezes, também Pílulas Vitalizantes. Como a paciente não melhorasse, fomos chamados.

Além dos sintomas referidos. a mãe da menina notou que desde que ela adoeceu estava inapetente. com medo de comer, pálida, com olheiras, tornando-se cada vez mais abatida. Nos seus antecedentes pessoais constam além das doenças da infância (sarampo. varicela), difteria, furunculose e "larvas migrans", esta em 1947. A paciente é filha de um abastado industrial, vive no maior confôrto, e gozava de excelente saúde até então.

Antecedentes familiares: Pais vivos e sadios. Tem um irmão menor, de 9 anos, que também apresentou exame de fezes positivo para ovos de ancilostomídeo. mas no qual os sintomas da parasitose foram muito leves, desaparecendo após a primeira dose de vermífugo.

Exame físico: Trata-se de uma adolescente bem desenvolvida, com evidente obesidarle (apesar de ter emagrecido desde o início da presente moléstia), com ligeira palidez da pele e das mucosas visíveis. Clinicamente nada de anormal foi verificado ao exame do segmento cefálico, bem como dos aparelhos respira. tório e circulatório. O abdome, ligeiramente abaulado, simétrico, com excessivo desenvolvimerto da camada adiposa, apresentava uma cicatriz cirúrgica na fossa ilíaca direita. A palpação superficial do epigástrio despertava ligeira dor, $O$ fígado e o baço eram impalpáveis. Os segmentos intestinais eram palpáveis e indolores.

Solicitamos novo exame de fezes e contagem (21-3-49), e novo hemograma (vide quadros 5 e 6$)$. e indicamos sulfato ferroso $(0.325 \times 2)$ e complexo vitamínico, procurando melhorar a alimentação da paciente. Aconselhamos a suspensão de tôda a medicação de que vinha fazendo uso e indicamos uma dose de vermífugo (Cristoids), solicitando que as fezes evacuadas durante as 21 horas seguintes à administração do vermifugo fôssem encaminhadas para o lahoratório, para identificação dos vermes. Infelizmente apenas nos foi enviada uma peque. na amostra de fezes, na qual não se encontrou nenhum helminto.

Em 6-4-49 foi feita nova contagem de ovos nas fezes e administrada nova dose de vermífugo, o qual foi ainda repetido 15 dias depois (20-4-49). Já por 


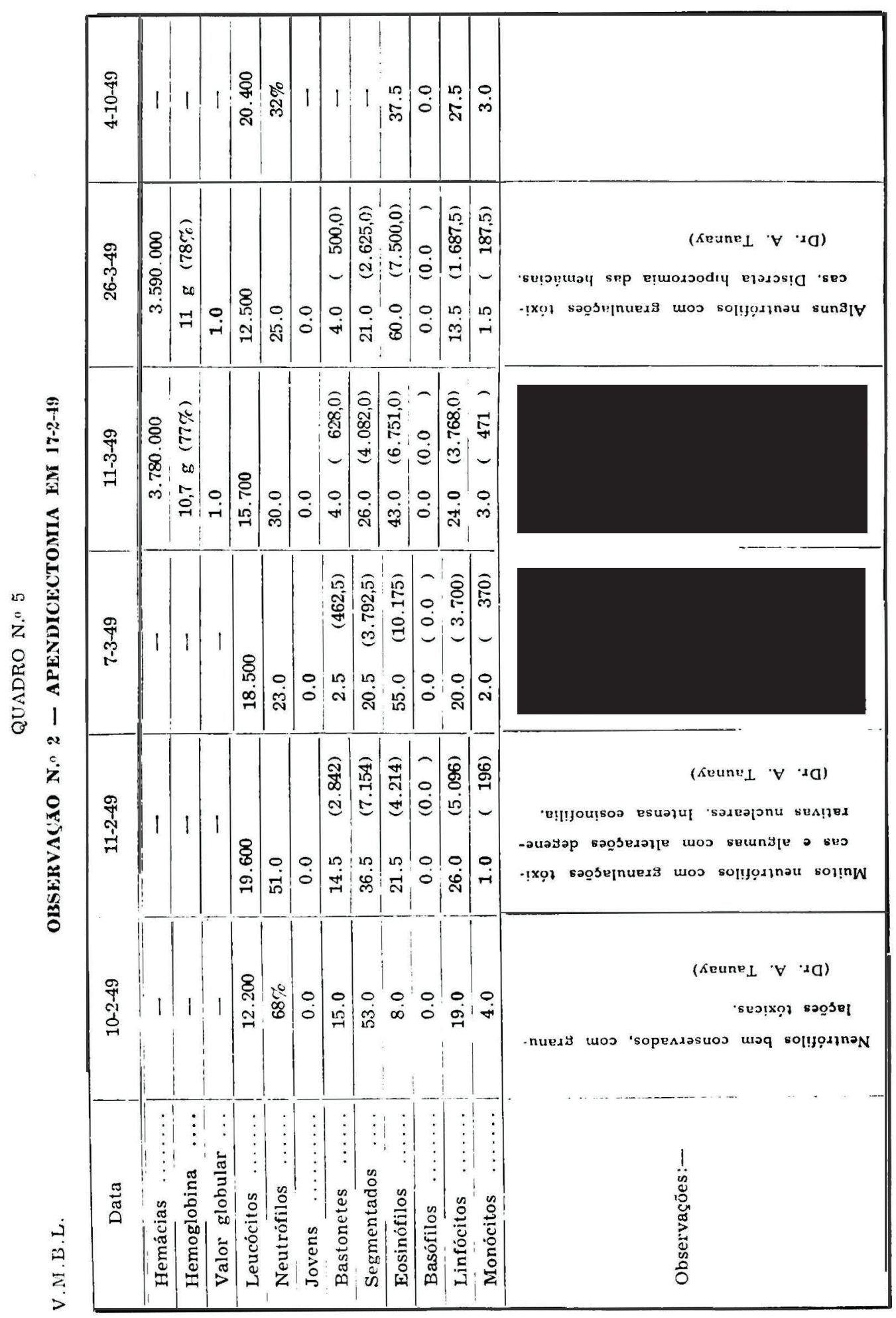


essa ocasião a paciente (15-5-49) passava bem. Não se queixava mais de dor epigástrica, as fezes readquiriram a consistência normal. $O$ apetite reapareceu e o pêso da paciente voltou ao anterior. Nessa data foi suspensa a medicação (sulfato ferroso e polivitaminas Vimagna Lederle).

Em 2-5.49 um novo exame de fezes para contrôle do tratamento acusou ainda raros ovos de ancilostomídeo, tanto pelo método de Willis como pelo de Faust. Foram feitas as preparaçöes para contagem de ovos de 2 amostras do material pelo método de Stoll, não encontrando nestas preparações nenhum ovo. Em 55-49 foi administrada nova dose de Hexilresorcinol, e em 21-8,49 o exame de fezes foi negativo. Foi pedido um exame hematológico, mas êste não foi feito em virtude de ser excelente o estado da paciente.

QUADRO N.० 6

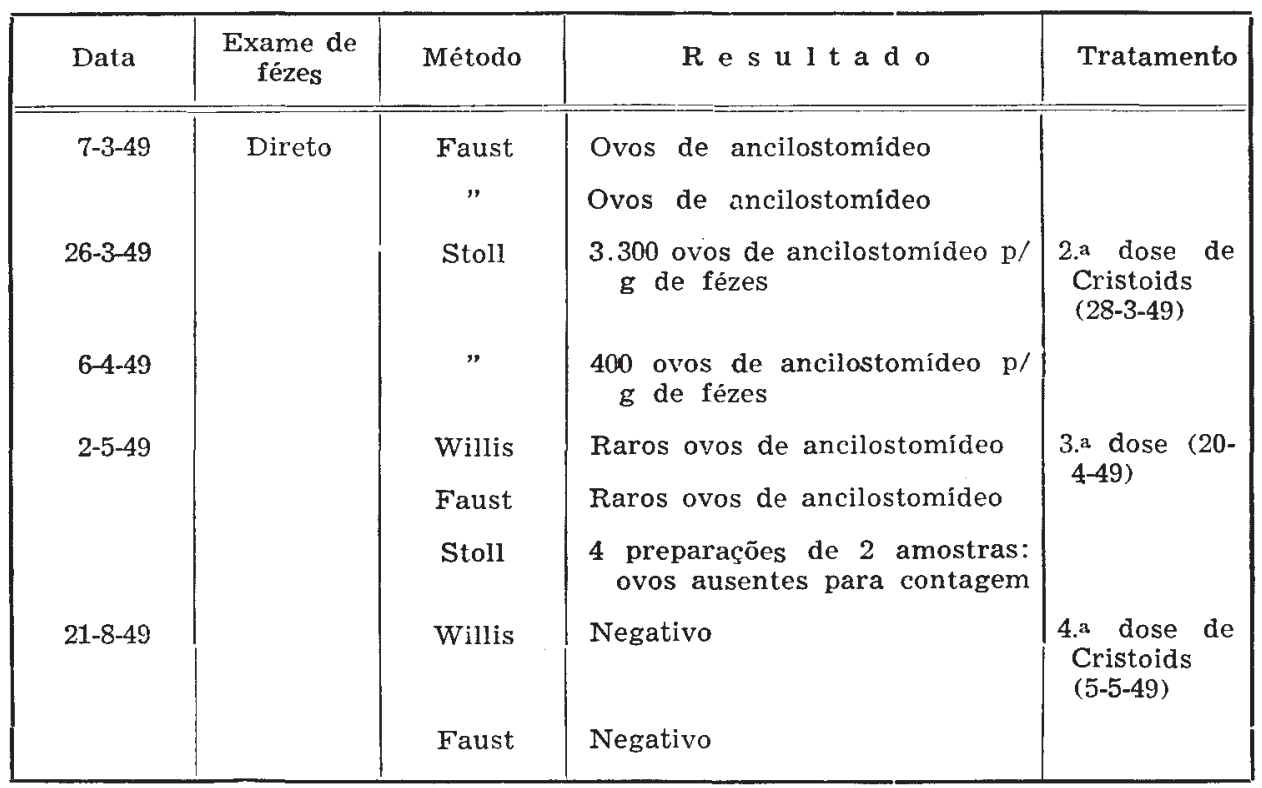

\section{COMENTÁRIOS}

Existem vários pontos de contacto entre os dois casos cujas observações acabamos de descrever e por isso ambos serão comentados ao meşno tempo.

Tanto num caso (L.A.T.L.) como no outro (V.M.B.L.) tratava-se de adolescentes, um de 9 anos, outro de 10 anos; um do sexo masculino, outro feminino; ambos brancos, filhos de famílias abastadas e residentes nesta Capital. F.m ambos a infecção ancilostomótica foi adquirida na praia, um caso em São Vicente (Praia Grande), outro no Guarujá. No primeiro caso (L.A.T.L.) pôde-se verificar que a infecção foi determinada pelo Ancylostona duodenale; no outro o ancilostomídeo não pôde ser identificado, pois não houve a mesma cooperação por parte da sua família para o necessário esclarecimento. No primeiro caso ficou evidente o dia exato da infecçāo, que se operou na manhã de 15 de novem- 
bro de 1948, quando o menor, em trajes de praia, brincou durante algumas horas na areia; no outro (V.M.B.L.), a aquisição da parasitose ocorreu também na praia, como dissemos, mas nāo podemos afirmar, como no primeiro caso. se a infecção foi única. Fm ambos os casos a sequência sintomatológica foi a mes. ma, embora a sua intensidade tenha sido diferente. Assim, observamos nos dois pacientes: prurido cutâneo, de duraçáo de cêrca de uma semana, particularmente intenso no primeiro caso. Fm seguida tosse sêca, espasmódica, acompanhada de rouquidão nos dois pacientes, e que persistiu por quase um mês num dêles e por mais tempo no outro (V.M.B.L.). Em seguida sobrevieram as dores abdominais. a princípio com caráter de cólica e depois contínua. A dor localizava-se no abdome superior, era sobretudo epigástrica e periumbilical, exacerbada pela ingestão dos alimentos e acompanhada de náuseas e vômitos num dos casos (I.. A.T.L.). A dor no caso n. 1 (L.A.T.L.) era intensa, a ponto de impedir o sono por muitas noites e resistir à medicação espasmódica habitual. Em ambos os pacientes verificou-se palidez, desânimo, astenia e emagrecimento. Os sintomas intestinais em ambos os pacientes foram caracterizados por evacuaçōes diarréicas, sendo em ambos os casos notada a presença de sangue, e sendo as diarréias 'pro. fusas principalmente num dos pacientes. Este último apresentou também febrícula. Nos dois casos houve a suspeita diagnóstica de apendicite, sendo um dos pacientes operado. Neste caso a persistência da sintomatologia após a apendicectomia sugeriu outros diagnósticos, como "púrpura de. Henock" e diverticulite.

No caso n. 1 (L.A.T.L.) ficou demonstrado que os ovos do Ancylostoma duodenale só apareceram nas fezes do paciente no $400^{\circ}$ dia após a infecção, porque tendo esta se realizado em 15-11-48, só em 24-12-48 o exame parasitológico acusou a presença de numerosos ovos de ancilostomídeo. Deve-se notar que no 30. dia após a infecção, em 14-12-1948, os exames de duas amostras de fezes dêsse paciente resultaram negativos. Entretanto (vide quadro 3.- observação L. A.T.L.). nessa época já havia leucocitose (16.500) e extrema eosinofilia $(11.5 \%$ -. 13-12-48). Esta observação coincide neste ponto com um dos casos de Ashford. Payne e Payne, no qual os ovos só foram encontrados no $19^{\circ}$ dia após a exposição. Também no quadro sanguíneo verificou-se nos 2 rasos grande coincidência. Em ambos havia anemia, sendo mais intenca no cuso n. 1 (L.A.T.L.) e dependente da maior espoliação sanguínea pelas evacuaçöes sanguinolentas. No caso n. 2 a anemia foi mais discreta, mas deve-se netar que as contagens dos glóbulos vermelhos não foram praticadas senão tardiamentc. Nos dois casos verificou-se hiperleucocitose intensa (até 51.300), alcancando os eosinófilos alé $55 \%$ (caso L.A.T.L.). No outro caso (V.M.P.L.) a leucocitose rhegon a 20.400 lencócitos por mm3 e os eosinófilos a $60 \%$.

Confirmando ainda as observações referidas anteriormente (Ashford Payne e Payne). notamos nos nossos casos que o quadro hematológico não se havia normalizado durante todo o período em que os pacientes foram observados. apesar de clinicamente se apresentarem curado: No I. caso (L.A.T.L.). em 22-9-19, portanto 10 meses após a infecção, havia ainda anemia hipocrônica e persistência da eosinofilia (11,5\%), embora os leueócitos houvessem laxixado para valores quase normais (6.800 por $\mathrm{mm} 3)$. No caso n." 2 (V.M.B.I.) a última contagem leucocilária, também 10 meses após a infecç̃ó ainda revelava leucocitose (20.400 leucócitos por mm3) e eosinofilia elevada $(37.5 \%)$.

Ainda os nossos casos demonstraram a rebeldia do tratamento e a necessidade da frequente repetição da medicarão antihelmíntica, a fim de se obter a 
completa erradicação dos vermes intestinais (o que não conseguimos senão em um dos pacientes na época em que escrevemos êste trabalho). Náo pudemos, por motivos alheios à nossa volltade, contar exatamente o número de vermes expulsos pelos pacientes. pois o material solicitado só nos foi encaminhado por um dêles e assim mesmo com períodos de interrupção. escapando. portanto. do nosso confronto uma parcela dos vernes eliminados. Não pudemos comprovar as observaçōes de Ashford. Payne e Payne quanto ao aspecto parasitológico dêsses casos, isto é. quanto à imaturidade dos vermes expulsos e predominância dos ver. mes machos, porque. como dissemos, nossas verificações nesse sentido foram in. suficientes.

Observando-se o quadro n." 4. correspondente à nossa ohservação n." I (L. A.T.L.). verifica-se um fato interescante e que merece alguns comentários. Assim é que as contagens de ovos pelo método de Stoll mostraram um progressivo decréscimo do número de ovos por grama de fezes durante o curso do tratamen. to antihelmíntico até 19-5-194.9, quando foram encontrados 500 ovos por grama de fezes. Entretanio, em 26-8-1949, foram avaliados em 8.500 os ovos existentes por grama de fezes. Durante êste intervalo o paciente estava sob tratamento antihelmíntico. recebendo em $12-4-1949$ a $6 .^{\mathrm{a}}$ dose de $0.80 \mathrm{~g}$ de Hexvlresorcinol cristoids. Como explicar estas flutuações nos resultados das contagens, ou, mais exatamente, a elevação verificada no número de ovos por grama de fezes em relação às contagens anteriores?

\section{()correm-nos as seguintes explicações:}

1) Reinfecção, o que não nos parece provável porque o paciente foi cuidadosamente instruido da maneira pela qual êle adquiriu a ancilostomose, e foram tomadas medidas para evitar a sua repetição, não nos constando mesmo que êle tenha sido exposto a uma reinfecção.

2) Defeito de técnica nas contagens ou êrro inerente ao método de Stoll. Essa possibilidade também não nos parece aceitável porque as contagens foram sempre feitas por pessoal experimentado, controlado por um de nós (L.A.A.C.) e o êrro imputável ao método seria muito grande para ser responável pelas diferenças verificadas nos resultados.

3) Que no intervalo que medeiou entre 19-5-1949 e 26-8-1919 outras larva: até então erruntes nos tecidos. tivessem chegado ao duodeno. completando aí a sua evolução e iniciado novas posturas. Não livemos elementos para comprovar esta possihilidade, que nos parece remola e puramente teórica, mas que nio pode ser inteiramente rejeitada. A queda verificada entre 26-8-1949 $\quad 18.500$ ovos por grama de fezes) e 17-11.1949 (2.200 ovos por grama de fezes). sem administração, nesse período. de nenhum vermífugo, poderia ser interpretada co. mo perda espontânea de um número correspondente de vermes. Infelizmente esisa explicação não pôde ser também comprovada. porque durante esse período as fezes do paciente não nos foram enviadas para pesquisa de helmintos porventura eliminados esponlâueamente.

4) Outra explicação que nos parece até certo fonto adinissivel é que a queda verificada nas contagens entre 3.2.1949 (11.400 ovos por rrama de fezes) e 19-5-1949 (500 ovos por grama de fezes) fôse devida em grande parte ao efeito 
inibitório sôbre as posturas das fêmeas do Ancylostoma duodenale pelo hexylresorcinol cristoids administrado nesse período, respectivamente, em 7-2-1949, 22.-2. 1949, 31-3-1949 e 12-4-1949. Se isto fôsse verdadeiro, teríamos uma causa capaz de falsear os resultados das contagens realizadas nesse período, e que prejudicaria a sua comparação com as contagens feitas posteriormente. Seria ainda aqui necessário têrmos prolongado por mais tempo e mais a miúde a contagem de vermes expulsos espontâneamente ou sob a ação do antihelmíntico, o que in. felizmente não pôde ser feito, como dissemos, por não ter sido o paciente hospitalizado.

Como vemos, os nossos casos reproduzem fielmente as observaçóes de Ashford, Payne e Payne, até en certas particularidades, como no fato da infecção ter ocorrido em ambos na praia, embora em ocasiōes diferentes.

Por último desejamos chamar a atenção para o fato de que, tante nos nossos casos, como nos outros referidos na literatura (Ashford, Payne e Payne; Hodes e Keefer; Rogers e Dammin e Whitehouse), o exame radiológico dos pulmões não assinalou alteração patológica em nenhum dos casos examinados aos raios $\mathrm{X}$. Este fato merece ser assinalado, em vista da sua importância diagnóstica com a chamada "eosinofilia tropical" e a síndrome pulmonar ensinofílica. Não desejamos entrar em consideraçöes sôbre o diagnóstico diferencial. A êsse propósito indicamos aos interessados os trabalhos de Walter Telles ${ }^{17}$ e Amaury Coutinho ${ }^{7}$, que estudam pormenorizadamente o assunto. Desejamos apenas assinalar que na presença de uma hiperleucocitose com hipereosinofilia deve ser considerada a possibilidade diagnóstica da fase larvária da infecção ancilostomótica. A anamnese cuidadosa e a sintomatologia clínica orientam nestes casos suficientemente bem o diagnóstico. Deve-se ter em mente que no período inicial o exame de fezes pode resultar negativo, como já chamamos a atenção, anies da chegada dos parasitos ao intestino e da postura ovular, podendo-se então incorrer no êrro diagnóstico considerando a hiperleucocitose com eosinofilia acentuada como fazendo parte do quadro de "Eosinofilia tropical".

\section{RESUMO}

Os A.A. apresentam 2 casos clínicos com os característicos descritos para a ancilostomíase aguda e consequentes à infecção maciça com larvas de Ancylostoma duodenale. Ambos os casos foram observados em crianças pertencentes a famílias abastadas, uma com 9 anos e meio, do sexo masculino, e outra de 10 anos e do sexo feminino.

Nos 2 casos, a ancilostomíase foi adquirida na praia, num caso na Praia Grande, em São Vicente, e noutro no Guarujá. Clìnicamente observou-se em ambos os casos a mesma sequência sintomatológica. Inicialmente prurido culâneo, intenso, em seguida tosse sêca e persistente e por fim sintomas agudos gastrointestinais. Dentre êstes últimos destacaram-se: a dor abdominal, intensa, contínua, localizada na região periumbilical e epigástrica; inapetência, náuseas, vômitos e diarréia por vézes sanguinolenta. Num caso havia, ainda, fehrícula. Em ambos observou-se emagrecimento. Em ambos os casos houve, por parte de outros médicos, suspeita diagnóstica de apendicite, sendo um dos pacientes submetido à apendicectomia. Hematològicamente foi verificado anemia intensa, num caso requerendo emprêgo de várias transfusões sanguíneas, e moderada no outro. 
Nos 2 pacientes o quadro leucocitário se caracterizou por hiperleucocitose, com elevada eosinofilia. Num dos casos foi possível verificar que se tratava de infecção pura por Ancylosioma duodenale e, no outro, em que o exame de fezes foi também positivo para grande número de ovos de ancilostomídeo, não se conseguiu, após a medicação antihelmíntica, identificar os helmintos. $\mathbf{0}$ desaparecimento dos sintomas clínicos só foi observado após a administração, repetida várias vêzes, do vermífugo. As alterações hematológicas persistiram durante todo o tempo de observação, máxime no que diz respeito à leucocitose e eosinofilia.

Os A.A. documentam seus casos com os exames subsidiários correspondentes, incluindo várias contagens de ovos nas fezes, antes e durante o tratamento, e exames hematológicos repetidos.

Tecem ainda consideraçóes sôbre os casos clínicos, frizando particularmente as possibilidades de êrro diagnóstico em casos semelhantes.

Chamam a atenção para a raridade da ancilostomose aguda e fazem, a respeito, uma revisão da literatura do assunto, discutindo a etiopatogenia dêstes casos, atribuida, consoante estudos recentes, à fase larvária da infecção ancilostomótica.

\section{SUMMARY}

The A.A. report two cases presenting the clinical features of an acute hookworm infection. The patients were well to do children, a boy 9 years old and a girl 10 years old. Both acquired the hookworm infection at sea-shore in S. Vicente (Praia Grande) and Guarujá near Santos, respectively. The symptoms showed by the patients were similar but those in the boy were more severe. Cuta. neous itching, persistent and non productive cough and acute gastro-intestinal disturbances were observed at first. Abdominal pain was localized in the epigastrium or umbilical region and accompanied by anorexia, nausea, vomiting, diarrhea and loss of weight and strenght. The presence of blood was verified in the faeces of both patients. Low grade fever of transitory character was observed in one of them. An incorrect diagnosis of appendicitis was made in both patients and one of them was submitted to the appendicectomy. The hematological changes were important and distinctive. Intensive anaemia was observed and in a patient requiring repeated blood transfusion while was only moderate in the other. The white blood count showed characteristic hyperleucocytosis and very high eosinophilia in both patients. Hookworm eggs were found in the stool examination in both cases but in only one was possible to identify the worms eliminated after the anthelminthic. So we had the proof that one of the cases was a pure Ancylostoma duodenale infection. The clinical improvement was obtained ouly after repeated anthelminthic treatment. The hematological alterations particularly the leucocytosis and eosinophilia were persistent for a long lime.

After discussing the diagnosis possibilities presented by their cases the A.A. emphazise the relative rarity of the acute hookworm infection and review briefly the literature. Then the A.A. discuss the etiopathogenesis and symptomatology of the larval stage of the hookworm infection. 


\section{REFERENCIAS BIBLIOGRAFICAS}

1 - Ashford, B. K.: Ankylostomiasis, In Byam W. \& Archibald R. G., The Practice of Medicine in the Tropics: 1923, vol. 3, pp. 1848-1873.

2 - Ashford, B. K. \& Gutierrez Igaravidez, P.: Uncinariasis en Puerto Rico: a medical and economic problem. Senate Document 808, Washington, Government Printing Office, 1911.

3 - Ashford, B. K., Payne, G. C., Payne, F.: The larval phase of Uncinarinsis. Puerto Rico J. Pub. Health \& Trop. Med., 9:97-134 (December) 1933.

4 -... Ashford, B. K., Payne, G. C. \& Payne, F. K.: Acute uncinariasis from massive infestation and its implications. - J.A.M.A, 101:843-847 (September, 9) 1933.

5 -.. Brumpt: Hookworm Therapy of Polycythemia Vera. J.A.M.A., 129:822 (November, 17) 1345 .

6 - Chandlex, A. C.: Hookworm Disease. The Macmillan Company, 494 pp. 1929.

7 - Coutinho, A.: Eosinofilia tropical. Estudo étio-patogénico, clínico e terapêutico. Tese de docência. Faculdade de Medicina da Universidade do Recife. Recife, 1949.

8 - Duvoir, M., Pollet, L. Brumpt, L. C. \& Chénebault, J.: Un cas de polyglobulie traité par ankylostomose provoquée (resultats favorables sur la polyglobulie et sur l'hypertension arterielle). Bull. et mém. Soc. méd. de hôp. de Paris, 56:42-45 (Mars, 15) 1940

G - Duvoir, M. \& Brumpt, L. C.: Le traitment des polyglobulies par l'ankylostomose provoqué (A propos de cinq cas). Ann. de parasitol., 90:25-42, 1944-1945.

1C - Faust, E. C.: Human Helminthology, 3.i ed., 1949, Lea \& Febiger, pp. 430 e seg.

11 -..- Hodes, P. J. \& Keefer, G. P.: Hookworm discase: small intestine study. Am. J. Roentgenol., 4:728-742 (December) 1945.

12 - Nagaty, H. F. \& Zanaty, A. F.: The treatment of Polycythoemia Vera. $A$ record of one case treated with Ancylostoma Infection. Tr. Roy, Soc. Trop. Med. \& Hyg., 42:493-499 (March) 1949

13 - Oswaldo Cruz, W.: Hookworm Anemia, a deficiency disease. - Proceedings of the Fourth International Congress on Tropical Medicine and Malaria. -- Washington, D.C., May, 10-18, 1948, vol. 2, pp. 1045-1052.

14 -.. Pessòa, S. B. \& Meira, J. A.: A eosinofilia sanguinea. Soc. Ed. Mćd. Ltda., Săo Paulo. 1935.

15 -- Rocha, Jr., M. da: Um caso curioso de ancylostomose. Eiasil med., 44:4-5 (janeiro, 4) 1930 . Idem Arq. Pediat, ?(16)523-524 (janeiro) 1930.

16 - Rogers. A. M. \& Tammin. G. J.: Hookworm infection in American troops in Assam and Buma. Am. J. M. Sc., 211:531-538 (Nay) 1946.

17... Telles, W.: Sindrome pulmonar eosinofilica. Tese de docencia. Fac. Nac Med. Rio de Janeiro, 1948

18 ... Weber, II. M.: Roentgenologic changes observed in tropical diseases. Am. J. M. $S(., 211: 629-636$ (May) 1946.

19 Whilehouse, F. R.: Massive eosinophulia in uncinariasis; report of 2 cases. Gastroenterology, 9:303-306 (September) 1947. 